\title{
Pelanggaran Prinsip Utmost Good Faith pada asuransi jiwa (studi kasus putusan nomor 352/Pdt.G/2013/Pn.Jkt.Sel
}

\author{
Satria Azis Widiarto \\ Magister Hukum Ekonomi, Universitas Indonesia \\ Email Korespondensi: satriaazis96@gmail.com
}

\begin{abstract}
Abstrak. Artikel ini membahas mengenai (1) Apakah alasan penolakan pembayaran klaim pada putusan nomor 352/Pdt.G/2013/PN. Jkt. Sel, antara Dahlan Sinambela sebagai penggugat melawan PT Axa Mandiri Financial service sebagai Tergugat sudah tepat menurut hukum asuransi?; (2) Bagaimana penerapan prinsip utmost good faith pada perkara antara dahlan sinambela melawan PT Axa Mandiri Financial Service pada tingkat pertama hingga tingkat kasasi?. Pada penelitian ini digunakan metode Yuridis-normatif sehingga data yang digunakan berasal dari studi kepustakaan. Hasil dari penelitian ini adalah (1) Penolakan pembayaran klaim polis nomor 512-6844199 tanggal 2 Maret 2012 atas nama Tertanggung Uli Sinambela sudah tepat menurut hukum asuransi, (2) Pengadilan Negeri belum menerapkan Prinsip utmost good faith sedangkan dalam tingkat Pengadilan Tinggi dan Kasasi Majelis Hakim telah menerapkan Prinsip Utmost Good Faith dengan benar.
\end{abstract}

\section{Kata kunci: Asuransi jiwa, klaim asuransi, Utmost Good Faith}

Abstract. This article discusses (1) The reasons for refusal to pay claims in decision number 352/Pdt.g/2013/PN.Jkt.Sel, between Dahlan Sinambela as the Plaintiff against PT Axa Mandiri Financial Services as the Defendant. Is it Correct according to insurance law? (2) How is the principle of utmost good faith applied in the case between Dahlan Sinambela and PT Axa Mandiri Financial Services at the first-class district court up to the cassation level? This study used to juridicalnormative method, so the data used came from literature studies. The result of this study are (1) the rejection of payment of policy claims number 512-6844199 dated March 2, 2012, on behalf of the insured Uli Sinambela is correct according to insurance law, (2) The district court did not apply the principle of utmost good faith while at the high court level and the court's cassation, the judge, has correctly applied the principle of utmost good faith.

Keywords: Life Insurance, Insurance claims, Utmost good faith

\section{PENDAHULUAN}

Asuransi adalah bagian yang tidak terpisahkan dari kehidupan manusia. Setiap manusia pasti memiliki risiko dan manusia memiliki berbagai cara untuk mengatasi risiko. Pada umumnya risiko yang dikenal dalam perasuransian terdiri dari risiko umum, risiko spekulatif, risiko individu, risiko harta dan risiko tanggung gugat. Risiko umum berarti tidak ada kepastian terjadinya suatu kerugian atau hanya ada peluang merugi dan bukan suatu peluang keuntungan dengan, sedangkan risiko spekulatif adalah risiko yang berkaitan dengan terjadinya dua kemungkinan, antara peluang mengalami kerugian finansial dan peluang memperoleh keuntungan. Risiko individu adalah risiko yang mempengaruhi kapasitas atau kemampuan seseorang memperoleh keuntungan yang dapat disebabkan mati muda, cacat fisik, dan kehilangan pekerjaan. Risiko harta adalah terjadi kerugian keuangan apabila kita memiliki suatu benda atau harta dimana adanya peluang harta tersebut hilang, dicuri atau rusak. Risiko tanggung gugat adalah risiko yang mungkin kita alami atau derita sebagai tanggung jawab akibat kerugian atau lukanya pihak lain.

Menurut Prof Emmy Pangaribuan, cara mengatasi risiko yakni terdiri dari avoidance, prevention, transfer, dan assumption or retention. Avoidance berarti adalah manusia akan menghindari atau menyingkir atau menjauhi dari suatu risiko, sedangkan prevention yaitu manusia akan mencegah supaya risiko tidak terjadi, kemudian transfer 
yaitu seseorang mengalihkan risiko kepada perusahaan asuransi, sedangkan assumption or retention yaitu seseorang akan menerima risiko tersebut tanpa menghindari, menjauhi menyingkir, mencegah ataupun mengalihkan risiko tersebut kepada perusahaan asuransi.

Asuransi menurut pasal 1 angka $1 \mathrm{UU}$ nomor 40 tahun 2014 tentang perasuransian adalah Perjanjian antara dua pihak, yaitu Perusahaan Asuransi dan pemegang polis, yang menjadi dasar bagi penerimaan premi oleh Perusahaan Asuransi sebagai imbalan untuk:

a. Memberikan penggantian kepada Tertanggung atau pemegang polis karena kerugian, kerusakan, biaya yang timbul, kehilangan keuntungan atau tanggung jawab hukum kepada pihak ketiga yang mungkin diderita Tertanggung atau pemegang polis karena terjadinya suatu peristiwa yang tidak pasti; atau

b. Memberikan pembayaran yang didasarkan pada meninggalnya Tertanggung atau pembayaran yang didasarkan pada hidupnya Tertanggung dengan manfaat yang besarnya ditetapkan dan/atau didasarkan pada hasil pengelolaan dana.

Berdasarkan definisi tersebut, asuransi merupakan suatu perjanjian. Perjanjian diatur di dalam pasal 1320 sampai dengan 1337 Kitab Undang-Undang Hukum Perdata (untuk selanjutnya disebut KUH Perdata) tentang syarat-syarat sahnya suatu perjanjian. Terdapat 4 (empat) syarat sahnya suatu perjanjian yaitu:

1. Sepakat mereka yang mengikatkan dirinya;

2. kecakapan untuk membuat suatu perikatan;

3. suatu hal tertentu dan;

4. suatu sebab yang halal

Kemudian berdasarkan pasal 1 Kitab Undang-Undang Hukum Dagang (untuk selanjutnya disebut KUHD) disebutkan bahwa "Kitab Undang-Undang Hukum Perdata, seberapa jauh daripadanya dalam kitab ini tidak khusus diadakan penyimpanganpenyimpangan, berlaku juga terhadap hal-hal yang dibicarakan dalam kitab ini". Kemudian di pasal 246 KUHD disebutkan bahwa
Asuransi atau pertanggungan adalah "suatu perjanjian, dengan mana seorang Penanggung mengikatkan diri kepada seorang Tertanggung, dengan menerima suatu premi, untuk memberikan penggantian kepadanya karena suatu kerugian, kerusakan atau kehilangan keuntungan yang diharapkan, yang mungkin akan dideritanya karena suatu peristiwa yang tak tentu".

Pada putusan nomor 352/Pdt.G/2013/PN. Jkt. Sel, antara Dahlan Sinambela sebagai penggugat melawan PT Axa Mandiri Financial service sebagai Tergugat, Penggugat merupakan ahli waris dari Almarhum Uli Sinambela (Bapak kandung Penggugat) selaku Tertanggung dan/atau pemegang polis Asuransi Jiwa Individu Mandiri Jiwa Sejahtera Nomor 5126844199 tanggal 2 Maret 2012 berdasarkan Surat Pengajuan Asuransi Jiwa tertanggal 24 Februari 2012. Polis asuransi itu dibekali dengan uang pertanggungan senilai Rp200.000.000,- (dua ratus juta Rupiah) dengan periode antara 2 Maret 2012 sampai dengan 1 Maret 2013 dengan menggunakan premi yang sifatnya tahunan sebesar Rp2.462.000,00 (dua juta empat ratus enam puluh dua ribu Rupiah). Kemudian pada tanggal 26 Mei 2012 Tertanggung (Almarhum Uli Sinambela) meninggal dunia karena sakit berdasarkan surat keterangan meninggal dunia nomor 54/SKMD/2005/V/2012 tanggal 31 Mei 2012 dan Kutipan akta kematian nomor 1201-KM-190620120001 tanggal 20 Juni 2012. Penggugat mendalilkan bahwa berdasarkan ketentuan pasal 5 angka 1 polis asuransi jiwa mandiri sejahtera nomor 5126844199 menyatakan "apabila Tertanggung meninggal dunia sebelum tanggal akhir kontrak, maka Penanggung akan membayarkan $100 \%$ (seratus persen) uang pertanggungan dan polis berakhir dan pada pasal 6 angka 1.1 polis asuransi mengatakan dalam hal kematian Tertanggung sebelum tanggal akhir kontrak, maslahat akan dibayarkan kepada penerima maslahat. Namun Tergugat (PT Axa Mandiri Financial Service) menolak untuk membayarkan maslahat tersebut karena diduga Tertanggung memberikan keterangan yang tidak benar pada 
saat pengisian SPAJ. Dari kronologis tersebut yang penulis susun berdasarkan putusan nomor 352/Pdt.G/2013/PN.Jkt.Sel, maka penulis akan membahas lebih lanjut mengenai:

1. Apakah alasan penolakan pembayaran klaim pada putusan nomor 352/Pdt.G/2013/PN.Jkt.Sel, antara Dahlan Sinambela sebagai penggugat melawan PT Axa Mandiri Financial service sebagai Tergugat sudah tepat menurut hukum asuransi?

2. Bagaimana penerapan prinsip utmost good faith pada perkara antara dahlan sinambela melawan PT Axa Mandiri Financial Service pada tingkat pertama hingga tingkat kasasi?

\section{METODE PENELITIAN}

Metode penelitian yang digunakan oleh penulis dalam membahas rumusan masalah dalam penelitian ini adalah menggunakan bentuk penelitian hukum yuridis normatif. Yuridis normatif disini adalah penelitian yang menggunakan data sekunder atau bahan pustaka. Data sekunder yang digunakan dalam penelitian ini adalah berupa peraturan perundang-undangan dan putusan pengadilan.

\section{HASIL DAN PEMBAHASAN}

A. Apakah alasan penolakan pembayaran klaim pada putusan nomor 352/Pdt.G/2013/PN. Jkt. Sel, antara Dahlan Sinambela sebagai penggugat melawan PT Axa Mandiri Financial service sebagai Tergugat sudah tepat menurut hukum asuransi?

Bahwa Tertanggung (Uli Sinambela) mengajukan Surat Permintaan Asuransi Jiwa tanggal 24 Februari 2012, dan kemudian terbit Sertifikat Polis Asuransi Jiwa nomor 5126844199 tanggal 2 Maret 2012 atas nama Tertanggung dengan masa pertanggungan mulai tanggal 2 Maret 2012 sampai dengan 1 Maret 2013 dengan nilai Pertanggungan sebesar Rp200.000.000,- (dua ratus juta Rupiah). Bahwa kemudian Tertanggung meninggal dunia pada tanggal 6 Juni 2012 berdasarkan surat dari kepala desa Aek Raso Kecamatan Sorkam, Kabupaten Tapanuli
Tengah nomor 54/SKMD/2005/V/2012 tanggal 31 Mei 2012 dan kutipan akta kematian nomor 1201-KM-19062012-0001 tanggal 20 Juni 2012 yang menyatakan Tertanggung (Uli Sinambela) meninggal dunia pada tanggal 26 Mei 2012 di desa Aek Raso, Kecamatan Sorkam Barat, Kabupaten Tapanuli Tengah dengan meninggalkan ahli waris bernama Dahlan Sinambela (Penggugat). Kemudian Penggugat mengajukan klaim kepada Tergugat melalui kantor perwakilan Tergugat di Sibolga namun Tergugat melalui surat nomor 27074/AMFS/CLM/IX/2012 tanggal 10 September 2011 (seharusnya 2012) mengatakan tidak dapat membayarkan klaim kepada Penggugat karena Tertanggung mempunyai riwayat rawat inap dengan diagnosa (batu) pada kandung kemih dan benign Prostate Hyperthrophy (prostate) pada tanggal 2 agustus sampai dengan 5 september di RSU Dr. FL. Tubing, Sibolga sebelum Polis terbit dan informasi tersebut tidak tercantum pada SPAJ. Kemudian Penggugat mengajukan klaim kembali melalui surat nomor 003/P/LOMSP/II/2013 tanggal 14 Februari 2013 perihal tagihan klaim asuransi namun surat tersebut tidak mendapat tanggapan dari Tergugat. Kemudian pada tanggal 13 Maret 2013 Penggugat mengajukan surat nomor 011/P/LO-MSP/III/2013 tanggal 13 Maret 2013 perihal somasi dan kemudian Tergugat memberikan tanggapan melalui surat nomor 008/CMU/AMFS/III/2013 tanggal 27 Maret 2013 perihal tanggapan atas somasi yang pada intinya Tergugat tetap pada keputusannya dalam surat nomor 27074/AMFS/CLM/IX/2012 tanggal 10 September 2011 (seharusnya 2012).

Bahwa dalam SPAJ tanggal 24 Februari 2012 Alm. Uli Sinambela mengisi dan mengajukan SPAJ dengan menjawab pertanyaan-pertanyaan Tergugat antara lain sebagai berikut:

a. Apakah anda dalam keadaan sehat? dijawab "Ya"

b. Sebutkan nama dan alamat dokter yang biasa anda kunjungi jika menderita sakit? dijawab "Tidak pernah ke dokter"; 
c. Kapan terakhir kali anda berkonsultasi dengan dokter, apa alasannya dan bagaimana hasilnya? dijawab "tidak pernah ke dokter";

d. Apakah anda pernah/sedang menderita penyakit/ gangguan/ kelainan pada sistem kemih dan kelamin, sakit pinggang, sakit/nyeri saat buang air kecil, saluran kencing, kencing batu/kencing berpasir, batu ginjal, kencing berdarah, kencing nanah, sakit prostate, gagal ginjal, penyakit kelamin? dijawab "Tidak";

Karena berdasarkan pertimbangan dan penilaian terhadap asumsi SPAJ diisi dengan benar dan jujur, maka Tergugat mengabulkan permohonan Alm. Uli Sinambela dengan menerbitkan Polis Asuransi Jiwa Individu Mandiri Jiwa Sejahtera nomor 512-6844199 tanggal 2 Maret 2012 dengan masa pertanggungan sejak tanggal 2 Maret 2012 sampai dengan tanggal 1 Maret 2013. Selain itu, Tergugat menolak klaim karena Penggugat tidak dapat memenuhi ketentuan pasal 5 ayat (1) polis, karena Tertanggung (Alm. Uli Sinambela) telah memberikan keterangan yang tidak benar atau tidak jujur dalam SPAJ sehingga melanggar prinsip asuransi non disclosure.

Selain itu, berdasarkan butir 12 halaman 8 SPAJ tentang Pernyataan dan Surat Kuasa khususnya butir 1 dan 2 menyatakan Tertanggung (Alm. Uli Sinambela):

1. Telah membaca, mengerti, menjawab dan mengisi semua pertanyaan pada Surat Permintaan Asuransi Jiwa ini beserta lampirannya dengan sebenar-benarnya, jujur, lengkap dan sesuai dengan keadaan sebenarnya;

2. Semua jawaban dan keterangan di atas merupakan dasar dan menjadi bagian yang tidak terpisahkan dari polis. saya/kami menyetujui apabila ternyata jawaban dan keterangan yang saya/kami berikan itu tidak benar, maka PT. Axa Mandiri Financial Service (perusahaan) berhak membatalkan polis yang dibuat atas dasar permintaan ini sejak awal, sesuai dengan ketentuan polis.

Kronologis tersebut diatas penulis susun berdasarkan putusan pengadilan nomor 352/pdt.g/2013/PN.Jkt.Sel.
Bahwa penolakan untuk melakukan pembayaran klaim atas asuransi jiwa Individu Mandiri Jiwa Sejahtera atas nama Tertanggung Uli Sinambela dengan nomor polis 5126844199 tanggal 2 Maret 2012 dengan masa pertanggungan sejak tanggal 2 Maret 2012 sampai dengan tanggal 1 Maret 2013 adalah sudah tepat menurut hukum asuransi sebagaimana diatur di dalam pasal $251 \mathrm{KUHD}$ menyatakan sebagai berikut:

"Setiap keterangan yang keliru, atau tidak benar, ataupun setiap tidak memberitahukan hal-hal yang diketahui oleh si Tertanggung, betapapun itikad baik ada padanya, yang pada demikian sifatnya, sehingga seandainya si Penanggung telah mengetahui keadaan yang sebenarnya, perjanjian itu tidak akan ditutup atau tidak ditutup dengan syarat-syarat yang sama, mengakibatkan batalnya pertanggungan"

Tentunya jika Tertanggung (Uli Sinambela) menjawab jujur pertanyaan dalam pengajuan SPAJ, maka Penanggung akan membayarkan maslahat meninggal jika Tertanggung meninggal dunia. Tetapi karena Tertanggung tidak memberikan informasi yang benar sebagaimana fakta, maka Penanggung berhak untuk tidak membayarkan maslahat meninggal dan batalnya pertanggungan. Hal tersebut sudah sesuai sebagaimana pasal 251 KUHD tersebut diatas.

B. Bagaimana penerapan prinsip utmost good faith pada perkara antara dahlan sinambela melawan PT Axa Mandiri Financial Service pada tingkat pertama hingga tingkat kasasi?

Pada pertimbangan hukum putusan nomor 352/pdt.g/2013/PN.Jkt.Sel disebutkan bahwa berdasarkan bukti-bukti yang diajukan oleh Penggugat dan Tergugat pada persidangan, Tergugat tidak dapat membayarkan klaim karena tidak sesuai dengan ketentuan Pasal 5 ayat (1) Polis dimana tertanggung (Alm. Uli Sinambela) telah memberikan keterangan yang tidak benar atau tidak jujur dalam SPAJ sehingga melanggar prinsip Non Disclosure. Namun majelis hakim setelah mempelajari perjanjian asuransi dalam polis nomor 512-6844199 tanggal 2 maret 2012 atas nama Tertanggung Uli Sinambela 
menyatakan bahwa tidak menemukan adanya hal-hal yang bertentangan dengan syaratsyarat sahnya suatu perjanjian sebagaimana dimaksud dalam pasal 1320 KUH Perdata sehingga perjanjian tersebut sah dan mengikat secara hukum. Kemudian majelis hakim mempertimbangkan mengenai jika permohonan Klaim Penggugat tidak dibayarkan oleh Tergugat dengan alasan bahwa Tertanggung telah memberikan keterangan yang tidak benar atau tidak jujur dalam SPAJ tentunya tidak dapat dibenarkan karena hal tersebut bukanlah mengenai pembayaran maslahat atas meninggalnya Tertanggung, akan tetapi pengakhiran Pertanggungan, disamping itu alasan Tergugat tersebut tidaklah termasuk dalam alasan-alasan dalam pasal 5 ayat (2) yang disebutkan bahwa Penanggung berhak tidak membayar maslahat apapun jika Tertanggung meninggal dunia sebelum akhir kontrak akibat:

2.1.Tindakan yang dilakukan oleh orang yang ingin mengambil keuntungan atas Pertanggungan ini, atau

2.2.Tertanggung dijatuhi hukuman mati, atau

2.3.Mengkonsumsi alkohol atau penyalahgunaan atau ketergantungan pada narkotika, zat lain atau obat-obatan tanpa resep, atau

2.4.Upaya melukai diri sendiri secara sengaja atau bunuh diri atau percobaan bunuh diri, atau

2.5.Perang (baik dideklarasikan atau tidak), operasi sejenis perang, invasi, kegiatan militer, pemberontakan, demonstrasi, kerusuhan, kekacauan sipil, aktifitas kriminal atau ilegal, atau

2.6.Segala bentuk kecelakaan penerbangan selain sebagai penumpang pada penerbangan komersial yang terjadwal, atau

2.7.Partisipasi dalam olahraga atau aktivitas yang berbahaya seperti perlombaan (kecuali perlombaan dengan kaki), tinju, gulat, olahraga musim dingin, mengendarai kuda, olahraga dan aktivitas udara, olahraga air (kecuali berenang dan berlayar tanpa mesin), atau

2.8.Terkena reaksi nuklir, radiasi, ionisasi atau kontaminasi radioaktif dari nuklir, pengolahan limbah, bahan peledak atau senjata, atau

2.9.Pertanggungan tidak berlaku apabila dalam kurun waktu 1 (satu) tahun sejak tanggal polis dikeluarkan, Tertanggung bunuh diri.

Selain itu, Majelis Hakim Pengadilan Negeri Jakarta Selatan juga menyatakan dalam pertimbangan hukumnya yaitu jika permohonan klaim Penggugat tersebut tidak dibayarkan oleh Tergugat dengan alasan bahwa Tertanggung telah memberikan keterangan yang tidak benar atau tidak jujur dalam Surat Permintaan Asuransi Jiwa tentunya tidak dapat dibenarkan karena hal ini bukanlah mengenai pembayaran Maslahat atas meninggalnya Tertanggung akan tetapi pengakhiran pertanggungan, disamping itu alasan Tergugat tersebut tidaklah termasuk dalam alasan-alasan dalam Pasal 5 ayat (2) tersebut diatas.

Kemudian pada tingkat banding yaitu dalam putusan nomor 458/PDT/2014/PT.DKI dalam pertimbangan hukumnya disebutkan bahwa Pembanding semula Tergugat menolak pembayaran klaim polis atas meninggalnya Uli Sinambela karena tidak memenuhi ketentuan pasal 5 ayat (1) polis dimana Tertanggung telah memberikan keterangan yang tidak benar atau tidak jujur dalam SPAJ sehingga melanggar prinsip asuransi Non Disclosure. Majelis hakim Pengadilan Tinggi tidak sependapat dengan Pertimbangan Pengadilan Negeri Jakarta Selatan yang menyatakan polis nomor 512-6844199 atas nama Tertanggung Uli Sinambela sah dan mengikat secara hukum. Majelis hakim Pengadilan Tinggi tidak menemukan hal-hal yang bertentangan dengan syarat-syarat sahnya suatu perjanjian sebagaimana dimaksud dalam pasal 1320 KUH Perdata. Kemudian Majelis Hakim Pengadilan Tinggi menyatakan bahwa dalam membuat Perjanjian Asuransi Jiwa tidak hanya terikat pada pasal $1320 \mathrm{KUH}$ Perdata, tetapi juga terikat dengan ketentuan yang terdapat dalam KUHD yaitu khususnya pasal 251 KUHD. Kemudian pada lampiran polis yang berupa SPAJ, pada angka 12 tentang pernyataan dan surat kuasa pada butir (2) disebutkan "Semua jawaban dan keterangan diatas merupakan dasar dan menjadi bagian 
yang tidak terpisahkan dari polis. Saya/kami menyetujui bahwa apabila ternyata jawaban dan keterangan yang saya/kami berikan itu tidak benar, maka PT Axa Mandiri Financial Service berhak ("Perusahaan") berhak membatalkan polis yang dibuat atas dasar permintaan ini sejak awal, sesuai dengan ketentuan polis". Kemudian majelis hakim Pengadilan Tinggi menyatakan bahwa Tertanggung apabila memberikan keterangan yang tidak benar, maka Penanggung berhak untuk membatalkan polis yang dibuat atas permintaan tertanggung. Kemudian Majelis Hakim Pengadilan Tinggi berdasarkan segala pertimbangan, maka menurut Pengadilan Tinggi oleh karena Tertanggung ketika mengajukan SPAJ telah memberikan keterangan, pernyataan serta penjelasan yang tidak benar, maka perjanjian Asuransi Jiwa Sejahtera yang tertuang dalam Asuransi Mandiri Jiwa Sejahtera Plan tahunan nomor 512-6844199 adalah tidak sah dan harus dibatalkan, sehingga Petitum gugatan Terbanding semula penggugat harus ditolak.

Kemudian dalam pertimbangan hukum putusan nomor $1420 \mathrm{~K} / \mathrm{Pdt} / 2015$ disebutkan bahwa Putusan Judex Facti Pengadilan Tinggi Jakarta yang membatalkan Pengadilan Negeri Jakarta Selatan sudah tepat dan benar serta tidak salah menerapkan hukum dengan pertimbangan bahwa Tergugat telah dapat membuktikan bahwa Uli Sinambela (Tertanggung) telah berbuat tidak jujur dalam memberikan keterangan tentang riwayat kesehatannya pada saat pengajuan permintaan asuransi jiwa kepada Tergugat, bahwa berdasarkan pasal 251 KUHD, perjanjian pertanggungan tersebut/asuransi batal karena tidak memenuhi azas non disclosure. Berdasarkan pertimbangan tersebut, ternyata Putusan Judex Facti Pengadilan Tinggi Jakarta dalam perkara ini tidak bertentangan dengan hukum dan/atau undang-undang, maka permohonan kasasi yang diajukan oleh pemohon kasasi tersebut harus ditolak.

$$
\text { Pada putusan nomor }
$$

352/Pdt.g/2013/PN.Jkt.Sel Majelis hakim yang memeriksa dan memutus perkara tersebut tidak menerapkan prinsip utmost good faith. Majelis hakim hanya fokus pada bahwa perjanjian asuransi dalam polis nomor 5126844199 tanggal 2 Maret 2012 atas nama Tertanggung Uli Sinambela tidak bertentangan dengan syarat sahnya perjanjian sebagaimana diatur dalam pasal 1320 KUH Perdata. Selain itu Majelis Hakim memfokuskan diri pada pasal 5 ayat (2) polis berkaitan dengan Penanggung tidak akan membayarkan Maslahat jika Tertanggung meninggal dunia sebelum akhir kontrak sebagaimana telah penulis jelaskan diatas. Penulis disini berpendapat berbeda dengan Pertimbangan Majelis Hakim pada tingkat pertama karena berdasarkan pasal 1 KUHD disebutkan bahwa "Kitab Undang-Undang Hukum Perdata, seberapa jauh daripadanya dalam Kita ini tidak khusus diadakan penyimpanganpenyimpangan, berlaku juga terhadap hal-hal yang dibicarakan dalam kitab ini”. Tentunya Majelis Hakim seharusnya lebih menitik beratkan perkara ini kepada KUHD, bukan kepada KUH Perdata karena perjanjian asuransi adalah perjanjian yang sifatnya khusus dan diatur di dalam KUHD dan Undang-Undang Perasuransian. Kemudian terkait dengan polis asuransi tersebut, bahwa seharusnya Majelis Hakim lebih menitik beratkan perkara ini kepada Tertanggung tidak memberikan informasi yang tidak benar sehingga melanggar prinsip Non Disclosure, bukan kepada pasal 5 ayat (2) polis asuransi. Bahwa pemberian informasi yang tidak benar tersebut jika dikaitkan dengan pasal 251 KUHD maka pertanggungan menjadi batal.

Kemudian pada putusan Pengadilan Tinggi nomor 458/PDT/2014/PT.DKI Majelis hakim yang memeriksa dan memutus perkara tersebut sudah menerapkan prinsip utmost good faith dengan benar. Penulis sependapat dengan pertimbangan hukum majelis hakim karena dalam pertimbangan hukum putusan tersebut, Majelis hakim menyatakan bahwa Perjanjian asuransi tidak hanya terikat dengan ketentuan Pasal 1320 KUH Perdata, tetapi juga terikat dengan ketentuan pasal 251 KUHD. Majelis Hakim juga mempertimbangkan perihal lampiran polis pada angka 12 tentang pernyataan dan surat kuasa pada butir 2 yang disebutkan bahwa "semua jawaban dan keterangan diatas merupakan dasar dan 
menjadi bagian yang tidak terpisahkan dari polis. Saya/kami menyetujui bahwa apabila ternyata jawaban dan keterangan yang saya/kami berikan itu tidak benar, maka PT Axa Mandiri Financial Service ("Perusahaan") berhak membatalkan polis yang dibuat atas dasar permintaan ini sejak awal, sesuai dengan ketentuan polis". Sehingga berdasarkan hal tersebut Tertanggung apabila memberikan keterangan yang tidak benar, maka Penanggung berhak untuk membatalkan polis yang dibuat atas permintaan Tertanggung. Pada tanggal 8 Agustus 2011, 15 Agustus 2011, 19 Agustus 2011, 26 Agustus 2011 Tertanggung pernah dirawat jalan karena sulit buang air kecil dan dirawat inap pada tanggal 2 Agustus 2011 sampai dengan tanggal 5 September 2011, dan tanggal 23 September 2011 sampai dengan tanggal 24 september 2011 karena sulit buang air kecil. Berdasarkan hal tersebut, majelis hakim menyatakan bahwa ketika Tertanggung Uli Sinambela mengajukan SPAJ telah memberikan keterangan, pernyataan serta penjelasan yang tidak benar maka perjanjian asuransi dengan nomor polis 512-6844199 adalah tidak sah dan harus dibatalkan.

Kemudian pada putusan nomor 1420 K/Pdt/2015 Majelis Hakim dalam pertimbangan hukumnya menyatakan bahwa karena Tergugat telah dapat membuktikan bahwa Uli Sinambela (Tertanggung) telah berbuat tidak jujur dalam memberikan keterangan tentang riwayat kesehatannya pada saat pengajuan permintaan asuransi jiwa kepada tergugat dan berdasarkan pasal 251 KUHD Perjanjian pertanggungan/ asuransi tersebut batal karena tidak memenuhi azas non disclosure. Penulis sependapat dengan Majelis Hakim pada perkara ini karena pada tingkat banding telah terbukti bahwa Tertanggung tidak memberikan keterangan yang benar pada saat pengisian SPAJ sehingga Penanggung berhak untuk menolak membayarkan maslahat meninggal kepada ahli waris Tertanggung.

\section{KESIMPULAN}

Kesimpulan yang dapat diambil dari artikel ini adalah:
1. Penolakan pembayaran klaim polis nomor 512-6844199 tanggal 2 Maret 2012 atas nama Tertanggung Uli Sinambela sudah tepat menurut hukum asuransi;

2. Pada tingkat Pengadilan Negeri, Majelis Hakim tidak menerapkan prinsip utmost good faith, sedangkan pada tingkat Pengadilan Tinggi dan tingkat kasasi Majelis Hakim menerapkan prinsip utmost good faith dengan benar.

\section{SARAN}

Alangkah baiknya ketika melakukan penutupan asuransi, Calon Tertanggung memberikan informasi dengan sejujurjujurnya kepada Penanggung sehingga jika kelak terjadi risiko, Penanggung tidak bisa berdalih menolak untuk melakukan pembayaran klaim;

\section{DAFTAR PUSTAKA}

Emmy Pangaribuan Simanjuntak. (1980) Yogyakarta: Hukum Pertanggungan dan Perkembangan. Badan Pembinaan Hukum Nasional.

Tuti Rastuti. (2016). Aspek Hukum Perjanjian Asuransi. Yogyakarta: Medpress Digital.

Kornelius Simanjuntak, Brian Amy Prastyo, Myra R.B Setiawan. (2011). Hukum Asuransi. Depok : Djokosoetono Research Center FHUI.

Kitab Undang-Undang Hukum Dagang [Wetboek van Koophandel]. Diterjemahkan oleh R. Subekti dan R. Tjirosudibio. (2016). .Jakarta: PT Pradnya Paramitha.

Kitab Undang-Undang Hukum Perdata, [Burgerlijk Wetboek]. Diterjemahkan oleh R. Subekti dan R. Tjirosudibio. (2014). Jakarta: PT Balai Pustaka.

Undang-Undang nomor 40 tahun 2014 tentang Perasuransian, LN nomor 337 tahun 2014, TLN nomor 5618

Putusan nomor 352/Pdt.G/2013/PN.Jkt.Sel. Putusan nomor 458/Pdt/2014/PT.DKI. Putusan nomor $1420 \mathrm{~K} / \mathrm{Pdt} / 2015$ 